\title{
The implementation of Higher-Level Thinking Skills (HOTS) in History Education
}

\author{
Parimaladevi $^{1} \&$ Anuar Ahmad $^{2}$ \\ ${ }^{12}$ Faculty of Education UKM, MALAYSIA \\ E-mail: acupari920@yahoo.com
}

\begin{abstract}
Learning history is not just about learning the facts or events of the past but it is necessary to understand what is being taught and to analyze and generate new ideas about it to solve a problem or situation that students will encounter. Therefore, the element of High Level Thinking Skills (HOTS) that a student should possess will help students to achieve that level. High Level Thinking Skills (HOTS) is the ability to apply knowledge, skills and values in reasoning and reflection to solve problems, make decisions, innovate and create things. Malaysian Education Ministry has introduced the High Level Thinking Skills (HOTS) in the school system to produce young people with creative and critical thinking skills to deal with their own problems. In conjunction with that, the implementation of HOTS in History Education is expected to attract students to History subjects and to enhance the achievement of the students in this subject. In addition, the implementation of HOTS is also to create a situation where the quality of education system in Malaysia can compete with world level. This concept paper discusses the implementation of HOTS in History Education at Malaysia. The concept of High Level Thinking Skills (HOTS) is described in detail. Next, the issues faced by the teachers and the students are also explained. Finally, some suggestions for addressing the issues of HOTS implementation are outlined in this concept paper. Overall, this concept paper describes the implementation of Higher Level Thinking Skills (HOTS) in History Education.
\end{abstract}

Keywords: High Level Thinking Skills (HOTS), School system, History Education

\section{Introduction}

A high quality education system is one of the aspirations of any developing countries. The quality of National Curriculum determines the success of a country's education system as well as the value of human capital. Malaysia strives to provide world-class, high-quality education system. To achieve that, Malaysia's Ministry of Education places strong emphasis on designing curriculum which conforms to the international standard that embodies aspects of creativity, problem-solving and innovation. The aim of the national curriculum is to produce future generation that is wellrounded and well-versed with the $21^{\text {st }}$ century skills (Rajendran 2010). Students with mastery of the $21^{\text {st }}$ century skills possess critical, creative and innovative thinking skills and as a result enabling them compete on an international level. 
Thinking skills are one of the student aspirations stated in Malaysia Education Blueprint (MEB). Starting in 1994, Critical and Creative Thinking Skills (CCTS) had been introduced in the National Curriculum via KBSR and KBSM. After undergoing several changes in the education system, in 2011 Primary Standard-Based Curriculum was instituted and its secondary level counterpart, Secondary Standard-Based Curriculum followed suit in 2014. This move was seen as a step forward by the government to strengthen thinking skills by emphasizing the skill of reasoning.

In order to face global competition, the Education Ministry places a priority of High Order Thinking Skills (HOTS) in our school system. The main aim for that is to eradicate situations where the students only memorize what they learn; now they are to fully understand it too. It is also to encourage the students to use their highest thinking ability by mastering the skills of evaluation, application, analysis and creating (KPM 2014).

\section{The High Order Thinking Skills (Hots) Concept}

Critical and Creative Thinking Skills (CCTS) was introduced into the National Curriculum in 1994 through KBSR and KBSM. High Order Thinking Skills (HOTS) made its debut by the Education Ministry in 2013 through shifts in the curriculum, pedagogy and evaluation. High Order Thinking Skills (HOTS) is one of the six elements of student aspirations in the Malaysia Education Blueprint (MEB) 2013-2025 which include leadership skills, thinking skills, bilingual skills, ethics and spirituality, social identity and knowledge needed for every student to be able to compete globally. Of those elements, thinking skills is the utmost important (Mohd Radzi, 2010).

High Order Thinking Skills (HOTS) are the ability to apply knowledge, skills and values in reasoning and reflecting when solving problems, making decisions, innovating and creating. According to Onosko \& Newmann (1994), High Order Thinking Skills (HOTS) is the ability of utilizing the potential of the mind to face new obstacles. HOTS cover 4 skills namely critical thinking, creative thinking, reasoning skill and thinking strategy. Critical thinking skill is the ability of evaluating an idea logically and rationally and making a wise judgment based on sound reasons and proof. Creative thinking skill refers to the ability to produce or create something new and valuable using original imagination plus thinking outside the box. If an individual is able to make judgment and evaluation logically and rationally, he is said to have used the reasoning skill. The thinking strategy is a structured and focused way of thinking to solve a problem (Standard Document of Curriculum and Evaluation for History Form 1 2017). Rajendran (2010) states that High Order Thinking Skills (HOTS) is the pinnacle in the hierarchy of cognitive process. He also says that when a person receives a new piece of information he will first save it in his memory before organizing it, associating it with his previous knowledge and creating a new concept based on that information to solve a problem or situation.

This element emphasized in HOTS is based on the reviewed Bloom's Taxonomy Hierarchy by Lori Anderson (1900) which consists of remembering, understanding, applying, analyzing, evaluating and creating. At the remembering level the students can recall information, facts or concepts learned. At the understanding level the students are able to recall as well as explain the information, facts or concepts learned.

At a rank higher, the applying level, the students apply the information, facts or values learned in different situations to solve problems. The students can break down information into smaller chunks to further understand its network at the analyzing level. At the evaluating level, the students can make judgments and decisions using knowledge, experience, skills and values while able to justify said actions. Finally, the students will come up with an idea or a product or a creative and innovative method at the creating level

\section{High Order Thinking Skills (Hots) In Learning History}

The teaching and learning of History have always been debated among the society, academics and students because they are thought to be behind the times and uninteresting. Such perception results in the subject performance to be just satisfactory (Rajendran 2010). To help overcome this problem, elements of HOTS have been included in the teaching and learning of History.

History is always seen as a subject that is hard to score due to the huge amount of facts required to be memorized. Students need to remember them all as failure to do so would affect their performance in the examination negatively. The fact is with HOTS students need not to memorize all historical facts anymore, all that is needed is the use of historical skills to assist in answering HOTS questions. HOTS not only produces students who can pass the examination but also those with healthier minds who are able to think rationally, critically and creatively, who will eventually stand tall when faced with a multitude of national challenges. Therefore, it can be said that HOTS does not create memorizers but students who are smart to evaluate and analyze facts critically. 
According to Abdul Rahim Abdul Rashid (1999), History educators need to pay more attention to the importance of analyzing and delving deeply into critical issues be they explicit or otherwise. Besides, learning History should be critical and challenging the students' thinking to understand the subject from a critical perspective. This is because studying History is far beyond the scope of facts or what happened in the past. It is also understanding the subject contents and analyzing as well as generating new ideas that will help the students solve future problems or situations. Being equipped with HOTS will prepare the students to reach that new height.

Learning History, too, requires the students to not simply accept facts or information received without thinking but to evaluate and compare them. With HOTS, the students will have the opportunity to compare, organize, classify and identify the cause and effect based on their opinions. For example, if a HOTS question is presented to a student, it can be answered in a variety of ways with new ideas coming from different angles. Not everyone will produce a similar answer. The difference in responses resulted from the different ways of thinking we all have. Some students think outside the box and their replies illustrate that while at the same time make the rest of the class think and debate among themselves, even with the teacher. When this happens, creative, innovative and creating thinking are born resulting in History being liked more by the students. The students will become more interested in learning the subject so they will pay more attention when lessons take place. The teaching and learning process will be more appealing and active too.

To ensure the success of MEB, HOTS begins its implementation in the areas of evaluation and public examinations. The Education Ministry has increased the ratio of HOTS questions in the School-Based Evaluation (SBE) and public examinations starting 2013. In 2014, the Education Ministry planned and changed PMR to PT3. In PT3, all subjects would include HOTS questions. For History, the written examination has been replaced with coursework or a case study in which the students need to research a given topic by visiting some places. HOTS is needed to complete the assignment. This shift designed by the Education Ministry helps the students to score in PT3 and indirectly retains their interest well into SPM. In 2019, the PT3 format for History undergoes another change with the HOTS elements remain. In SPM, History has been made a compulsory subject to pass beginning 2013. Since 2013 the subject has 3 papers in SPM. Paper 2 was introduced in 2005 and HOTS made its first presence in 2006.

\section{Issues In Implementing High Order Thinking Skills (Hots) In Learning History}

High Order Thinking Skills (HOTS) results in students with potential to use knowledge, skills and values to think and make judgment. However, its implementation is not without challenges and issues coming from the students and teachers.

\subsection{HOTS Issues among the Teachers}

The teacher readiness is an important element in executing HOTS in the classroom (Rajendran, 2001; Normah, 2013). A teacher needs to make preparations in advance before carrying out a lesson involving HOTS to avoid classroom disorganization. Fathiyah (2010) and Ghazali (2010) echo the aforesaid statement, adding that even if a teacher is wellversed in HOTS and fully aware of its importance, the absence of readiness would hinder the implementation of those thinking skills during the lesson. It can be deduced that this unreadiness stems from the lack of knowledge on how HOTS can be implemented in the classroom. A thoughtful, concerned teacher needs to prepare questions that are not routinely used. Routine questions refer to those which need analysis and reasoning.

In addition to that, the teaching method employed by the teachers is also an issue in carrying out HOTS. Teachers need to vary teaching techniques to successfully interest the students so that the learning objectives are achieved. Research shows that most teachers are still fond of conventional way of teaching which is teacher-centred. Siti Hawa Abdullah (2008) in her investigation states that teachers still rely heavily on textbooks. In such a lesson only the teacher speaks while the students just listen. They are not given the opportunity to voice their opinions or time to share their ideas during the lesson. The teacher needs to ask questions to elicit ideas from the class.

The next issue is the lack of skills in asking HOTS questions among the teachers. Teachers need to know the level of questions asked in the class. If questions belonging to the same level or low levels are frequently used then the students in that class have slim chances to think creatively and critically. Even low achievers need to be encouraged to think outside the box using the right questions. Teachers need to let the students speak and listen to what they say without interrupting mid-sentence even though what is said is off on a tangent. Rejendran (2001) says that almost $90 \%$ of the questions used by teachers belong to low level thinking skills. With only $10 \%$ coming from high level thinking skills, teachers need to strike a balance by forming questions from all levels. 
Then, there is the challenging issue of lack of time to implement HOTS in the classroom. Teachers need to complete their syllabus before examination, particularly classes sitting for public examinations. Thus, there is shortage of time to apply HOTS-based exercises in the classroom. Teachers are racing against time to cover all topics at least a month prior to the examination to do revision. This is agreed by Pushpalatha (2006) who says that teachers are of the opinion that gearing students for the examination and improving their cognitive skills are two different teaching objectives.

\subsection{HOTS issues among the Students}

The aims of HOTS application in a classroom can be attained if the pupils in that class participate actively during lesson. Rajendran (2001) also thinks that teachers need active students to carry out HOTS activities. Passive students cannot materialize the aims during lesson because they usually do not speak out in discussions and tend to just listen to what others say. They more often than not stay silent although they know the answers to the questions. This certainly fails the learning objectives involving HOTS.

Lack of knowledge of subject matter among students is also an issue. Students with little knowledge cannot answer HOTS questions. This has a direct effect on their thinking skills in a negative way. They would become lazy to give opinions. Yee.et. (2010) states if students rarely use high order thinking skills to generate ideas they will have problems in completing tasks. When asked to answer a technical question, the students would usually skip it because of the way it is usually formed: they are wordy and difficult to understand making them lazy to read much less think.

There is also a communication problem faced by the students that is said to be an issue. There are those who do not like to communicate with other students as well as their teachers. They are shy and filled with anxiety, hindering them from giving opinions when asked. They also do not cooperate when given group tasks. This causes HOTS implementation to fail.

\section{Suggestions To Overcome The Issues Of High Order Thinking Skills (Hots) In History}

HOTS can only succeed with the cooperation of both teachers and students. Exposure of HOTS should be a huge agenda in our national education system so that both parties become aware of the importance of HOTS and its use in producing academic high achievers who are on par with international students.

Teachers need to work hard to ensure the success of HOTS implementation in the classroom. They need to utilize a cocktail of teaching strategies to encourage students to think critically and participate actively during lessons. Teachers also need to increase the number of HOTS questions in the classroom. At the same time, students should get opportunities to an expression of opinion on the topic being discussed.

Next, 21st century learning should be carried out in the classroom to create an interesting learning atmosphere. This will result in the students participating more in the class unlike before. Examples include the use of ICT and group work. Without realizing it, such conducive environment not only helps the students learn but also optimizes their thinking skills at the levels of analysis, synthesis and evaluation. Assessments should be done to test the students skill throughout the year in the classroom not limited to traditional examination. Presentation, quizzes and coursework are other ways of assessing the students.

Another tool in the toolbox with a lot of promise to solve HOTS issues is i-THINK based lessons coupled with project-based learning and product-making. These are not new so are all teachers compliant with the Education Ministry policy? Teachers need to be responsible in obeying the directives coming from the ministry. There are 8 visual mind maps that are easy to understand and applicable across curriculum namely the Circle Map, Tree Map, Bubble Map, Double Bubble Map, Flow Map, Multi-Flow Map, Brace Map and Bridge Map. They can all be used in the classroom. Teachers can ask their students to create their own notes using any of the aforementioned maps. Projects can be assigned to be carried out in groups. The project or assignment given needs to be challenging to stimulate their minds to encourage them to think creatively in completing the task.

School administrators need to work in tandem with teachers to overcome these issues. HOTS related courses should be given from time to time to equip the teachers with the skills they need. This in turn convinces the teachers to make necessary preparations before teaching. The school administrators also need to increase their frequency of monitoring to ensure that all the necessary boxes are ticked and work to create classrooms which are 21 st-centurylearning-compatible.

\section{Conclusion}

Page | 219 
In conclusion, HOTS enhances students' understanding and achievement in the History subject. This element of HOTS will avoid situations like students fail to answer the examination or sleep due to lack of interest, traditional and less interesting learning techniques. Besides, through HOTS students are encouraged to face a challenge and take the risk to solve it in new ways. Implementation of HOTS in History subject enables students to do conclusions based on logic, evidence-based reading and research. The prediction which is based on the cause, effect and propose of solutions can help in creating rational ideas. Therefore, the High Level Thinking Skills Program (HOTS) is a useful way of implementing reforms in the education system in our country. At the same time, it will also improve and become an important way of improving the academic performance of students compared to the world.

\section{References}

[1] Abdullah, A.H., Aris, B., Saud, M.S., Boon, Y. , \& Awang Ali, S.A. 2015. Pelaksanaan Kemahiran Berfikir Aras Tinggi (KBAT): Isu dan Cabaran dalam Aspek Kurikulum, Pedagogi dan Pentaksiran. Seminar Kebangsaan Majlis Dekan-Dekan Pendidikan Universiti Awam 2015, 14-15 September 2015, p. 77-88.

[2] Awang Ali, S.A., Abdullah, A.H., Abd Halim, N.D., \& Ali, D.F. 2016. Tahap Pengetahuan dan Amalan Guru Matematik Sekolah Menengah terhadap Pelaksanaan Kemahiran Berfikir Aras Tinggi (KBAT). Malaysian Journal of Higher Order Thinking Skills in Education. Edition 1/2016, p.4275.

[3] Baharuddin Bin Jabar.2 006. Persektif Pelajar Terhadap Pengajaran Kemahiran Berfikir Aras Tinggi Dalam Pengajaran dan Pembelajaran Sejarah Di Sekolah Menengah : Satu Kajian Kes Di Daerah Hilir Perak.

[4] Bahagian Pendidikan Guru (Edisi Percubaan). Kemahiran Berfikir Secara Kritis dan Kreatif: Unit Empat. DSKP Sejarah Tingkatan 12017

[5] Halim Arifin. (2013). Kemahiran Berfikir dalam Pengajaran Pemahaman Bacaan. Tesis Dr Falsafah. Fakulti Pendidikan, Universiti Malaya, Kuala Lumpur.

[6] Ismail, M.S., Yee, M.H., Tee, T.K., \& Mohamad, M.M. 2015. Kepentingan Gaya Pembelajaran dan Kemahiran Berfikir Aras Tinggi dalam Kalangan Pelajar Teknikal. Seminar Kebangsaan Majlis Dekan-Dekan Pendidikan Universiti Awam 2015, 14-15 September 2015, p.189-196. Universiti Tun Hussein Onn Malaysia.
[7] Kementerian Pendidikan Malaysia. 2013. Pelan Pembangunan Pendidikan Malaysia 2013- 2015. Putrajaya: Bahagian Pembangunan Kurikulum.

[8] Lembaga Peperiksaan. 2013.Pentaksiran Kemahiran Berfikir Aras Tinggi. Kementerian Pendidikan Malaysia, Kuala Lumpur.

[9] Mohd Radzi, M.S. 2010. Aplikasi Kemahiran Berfikir Aras Tinggi melalui Pembelajaran Berasaskan Masalah. Johor Bahru: Fakulti Pendidikan Universiti Teknologi Malaysia. Tesis Sarjana Muda.

[10] Noraini Omar. (2015). Amalan pengajaran guru Pendidikan Islam berfokuskan kepelbagaian budaya murid: kajian kes di Negeri Sarawak. Tesis Dr. Falsafah. Fakulti Pendidikan. Bangi, Universiti Kebangsaan Malaysia.

[11] Nor Hasmaliza Hasan. 2016. Penerapan kemahiran berfikir aras tinggi (KBAT) dalam pengajaran guru Bahasa Melayu daerah Kuala Terengganu. Tesis Projek Sarjana Pendidikan. Fakulti Pendidikan, Universiti Kebangsaan Malaysia.

[12] Pushpalatha A/P Sivamugam.2006. Kemahiran Berfikir Aras Tinggi Dalam Sukatan Pelajaran Sejarah Tingkatan Empat : Satu Kajian Kes.

[13] Rajendran, N.S. 2010. Teaching \& Acquiring Higher-Order Thinking Skills: Theory \& Practice. Tanjung Malim: Penerbit Universiti Pendidikan Sultan Idris.

[14] Rajendran, N. 2001. Pengajaran Kemahiran Aras Tinggi (KBAT): kesediaan guru mengendalikan proses pengajaran dan pembelajaran. Kertas kerja dibentangkan di Seminar Projek Kemahiran Berfikir Kritis dan Kreatif (KBKK): Pusat perkembangan kurikulum KPM.

[15] Siti Hawa Abdullah.2008. Empati Sejarah Dalam Pengajaran Dan Pembelajaran Sejarah. Jurnal Pendidik dan Pendidikan, 28(1), pp.131 -146.

[16] Surif, J., Ibrahim, N.H., Abdullah, A.H., \& Boon, Y. 2016. Kemahiran Berfikir Aras Tinggi dalam Pengajaran dan Pembelajaran. Johor Bahru: Penerbit Fakulti Pendidikan Universiti Teknologi Malaysia.

[17] Tajul Ariffin Nordin (2010). Pendidik Bina Kebenaran Universal. Kuala Lumpur: Dewan Bahasa dan Pustaka

[18] Yee, M.H., Md Yunos, J., Othman, W., Hassan, R., \& Tee, T.K. 2010. Penggunaan Kemahiran Berfikir Aras Tinggi Marzano dalam Penjanaan Idea. Prosiding Seminar Dekan-Dekan IPTA 2010. Shah Alam: Universiti Teknologi MARA p. 60-73, 2-3 Ogos 2010 